INFORMASI: Kajian Ilmu Komunikasi-ISSN (p) o126-065o; ISSN (e) 2502-3837

Vol. 48. No. 2 (2018). Pp.213-227. doi: https://doi.org/10.21831/informasi.v48i2.21359

\title{
THE EFFECT OF SCIENCE TECHNOLOGY AND SOCIETY MODELS ON SCIENCE PROCESS SKILLS
}

\author{
Agatha Asih Nugraheni \\ agathaasih@gmail.com \\ Wuri Wuryandani \\ wuri_wuryandani@uny.ac.id \\ Universitas Negeri Yogyakarta
}

\begin{abstract}
This study aims to integrate the Science Technology and Society models on the students' processes in grade IV elementary school. The implementation of this study uses a quantitative approach with a type of quasi-experimental research. The population of the study sample was calculated from the second class, namely the fourth grade of SD Negeri Margoagung as the experimental class and class IV SD Ngino 1 as the control class. Data analysis is an independent sample t-test. The results showed that there was a significant influence of the Science and Community Technology model on the process skills of the fourth grade students of Seyegan Margoagung Group with a value of 0.751 and $p$ o.0oo <0.05. The Science Technology Model and the Unused Community. The Science Technology Model and Sociality are significant and positive in terms of process skills and student participation. This learning model can be applied to classes that can improve the process and involvement of students, students are easier to receive the material delivered by the teacher.
\end{abstract}

Keywords: Process, Science, Skills, Society, Technology

\section{PENGARUH MODEL SCIENCE TECHNOLOGY AND SOCIETY TERHADAP KETERAMPILAN PROSES SAINS}

\begin{abstract}
Abstrak
Penelitian ini bertujuan untuk menguji pengaruh model Science Technology and Society terhadap keterampilan proses sains siswa pada kelas IV SD. Pelaksanaan penelitian ini menggunakan pendekatan kuantitatif dengan jenis penelitian quasi eksperimen. Populasi sampel penelitian yang digunakan diambil dari dua kelas yaitu kelas IV SD Negeri Margoagung sebagai kelas eksperimen dan kelas IV SD Ngino 1 sebagai kelas kontrol. Analisis data yang digunakan adalah independent sampel t-test. Hasil penelitian menunjukkan bahwa terdapat pengaruh yang signifikan model Science Technology and Society terhadap keterampilan proses sains siswa kelas IV SD seGugus Margoagung Seyegan dengan nilai $t_{\text {hitung }}$,751 dan p o,000 <0,05. Model Science Technology and Society
\end{abstract}


berpengaruh terhadap keterampilan proses sains siswa. Model Science Technology and Sociaety berpengaruh secara signifikan dan positif ditinjau dari keterampilan proses sains dan partisipasi siswa. Model pembelajaran ini dapat diterapkan pada suatu kelas dapat meningkatkan keterampilan proses sains dan partisipasi siswa, sehingga siswa lebih mudah dalam menerima materi yang disampaikan oleh guru.

Kata Kunci: Keterampilan, Proses, Science, Society, Technology

\section{PENDAHULUAN}

Pendidikan merupakan hal penting yang harus dimiliki oleh setiap orang. Pendidikan menjadi sebuah simbol bahwa orang tersebut berhasil atau tidak dalam mengembangkan pengetahuan dan kepribadiannya. Hal tersebut tidak luput dari tujuan dasar pendidikan itu sendiri. Undangundang Nomor 20 tahun 2003 tentang Sistem Pendidikan Pasal 3 menyebutkan bahwa tujuan pendidikan adalah mengembangkan potensi peserta didik agar menjadi manusia yang beriman dan bertakwa kepada Tuhan Yang Maha Esa, berakhlak mulia, sehat, berilmu, cakap, kreatif, mandiri, dan menjadi warga negara yang demokratis serta bertanggung jawab. Berdasarkan uraian dari undang-undang tersebut, tugas pemerintah tentunya juga semakin berat. Menciptakan pendidikan sesuai tujuan pendidikan tersebut bukanlah hal yang mudah. Pendidikan yang berkualitas akan berpengaruh pada kehidupan individu, masyarakat dan bernegara. Berdasarkan hal tersebut maka pendidikan di sekolah-sekolah seharusnya dapat mewujudkan lingkungan yang kaya pengalaman, sehingga pendidikan dapat memenuhi kebutuhan perkembangan beragam kemampuan siswa yang berbedabeda.

Keberhasilan proses pembelajaran sebagai proses pendidikan di suatu sekolah tidak lepas dari pelaksanaan pembelajaran yang ideal. Pembelajaran yang ideal itu sendiri tidak hanya bertumpu pada guru saja, tetapi adanya interaksi antara guru dengan siswa. Selain itu rencana pelaksanaan pembelajaran juga harus dipersiapkan agar tercipta suasana pembelajaran yang baik dan ideal. Hal ini ditandai dengan jalinan komunikasi guru dan siswa yang harmonis. Pembelajaran tidak hanya berpusat pada guru (teacher centered) tetapi lebih berpusat pada siswa (student centered). Di mana dalam proses pembelajaran siswa dapat lebih aktif berpartisipasi dan membangun pengetahuannya sendiri. Keberhasilan suatu pembelajaran juga dipengaruhi oleh berbagai faktor. Faktor-faktor tersebut contohnya guru, siswa, kurikulum, lingkungan sosial, dan lain-lain. Seiring perkembangan jaman semakin banyak masalah-masalah yang di hadapi di Indonesia, mulai dari fasilitas sekolah, kelengkapan buku materi, pemahaman siswa, ketertarikan siswa, hingga kesiapan guru. Salah satu inovasi pemerintah untuk memajukan pendidikan saat ini adalah dengan adanya perubahan kurikulum yang disesuaikan dengan kemajuan jaman.

Salah satuaspek keterampilanyang harus dikuasai siswa adalah keterampilan proses sains. Penguasaan keterampilan proses sains dapat diambilkan dalam mata pelajaran IPA. IPA merupakan salah satu mata pelajaran yang sangat dekat dengan kehidupan siswa. Hal-hal yang dipelajari di dalam pembelajaran IPA sangat berkaitan dengan lingkungan sekitar siswa. Siswa diharapkan pembelajaran dapat mengembangkan pengetahuan, keterampilan proses, serta dapat memberikan pemecahan permasalahan yang ada di lingkungan sekitarnya. Berkaitan dengan hal tersebut tentunya tidak lepas dari pembelajaran yang menyenangkan, kreatif, dan inovatif agar siswa mendapatkan pengalaman yang bermakna dari pembelajaran IPA tersebut.

Pengembangan dan penguasaan konsep melalui belajar bagaimana mempelajari konsep, itulah yang disebut pengembangan keterampilan proses. Perkembangan dan pengajaran subyek didik diletakkan pada proses belajar tentang suatu konsep atau kejadian dalam lingkungan. Penguasaan keterampilan proses di sini merupakan hal penting untuk siswa dikarenakan merupakan 
cara yang khas dalam menghadapi pengalaman yang berkenaan dengan semua segi kehidupan yang relevan bagi siswa.

\section{KAJIAN PUSTAKA}

Ziman (1980:167) mengemukakan bahwa pembelajaran STS merupakan pembelajaran yang menggunakan teknologi sebagai penghubung antara sains dan masyarakat. Pembelajaran dengan model STS dapat digunakan sebagai penghubung/penerapan antara sains dan masyarakat sehingga siswa dapat memahami apa yang telah dipelajari. Sependapat dengan Poedjiadi (2010: 123) memaparkan model STS yang mengaitkan antara sains dan teknologi serta manfaat bagi masyarakat. Tujuan pembelajaran ini ialah untuk membentuk individu yang memiliki literasi sains dan teknologi serta memiliki kepedulian terhadap masalah masyarakat dan lingkungan.

Suatu pembelajaran pasti memiliki langkah-langkah yang harus ditempuh agar tujuan yang telah direncanakan dapat tercapai dengan apa yang diharapkan. Tahaptahap pelaksanaan pembelajaran melalui Science Technology and Society nampak pada bagian pembelajaran berikut ini (Poedjiadi, 2005:126).

\section{Tahap Pendahuluan}

Tahap ini siswa diberi kesempatan untuk menemukan pendapat mereka tentang sebab suatu kejadian satu pokok permasalahan. Kesempatan berdiskusi ini dapat meningkatkan keberanian siswa berbicara untuk mengemukakan mempertahankan pendapat. Hal ini dipergunakan untuk melakukan eksplorasi terhadap kemampuan siswa, sehingga guru dapat mengetahui seberapa jauh pemahaman siswa atas permasalahan yang dihadapi.

Selain itu, pada tahap pendahuluan ini adalah sebagai persiapan pelaksanaan. Guru menyiapkan beberapa wacana yang dapat diajukan sebagai masalah sesuai topik pelajaran. Selanjutnya guru memberi beberapa tugas untuk mengetahui pemahaman siswa terhadap pokok permasalahan.

\section{Tahap Pembentukan Konsep}

Tahap ini dilakukan melalui berbagai pendekatan dan metode. Misalnya dengan metode demonstrasi, eksperimen, diskusi kelompok, bermain peran dan lain-lain. Pada akhir pembentukan konsep diharapkan siswa telah dapat memahami analisis terhadap isu-isu atau penyelesaian terhadap masalah yang dikemukakan di awal pembelajaran. Setelah guru mengetahui pemahaman siswa, guru melanjutkan pembelajaran dengan pembentukan konsep melalui diskusi antar siswa dengan bimbingan guru. Pada tahap ini guru juga membimbing kegiatan siswa dalam mengerjakan soal seperti LKS.

\section{Tahap Aplikasi Konsep}

Pada tahap ini memotivasi siswa untuk mengemukakan pendapat mereka. Berbekal pemahaman konsep yang benar siswa melakukan analisis atau penyelesaian masalah yang disebut aplikasi konsep dalam kehidupan. Siswa dapat mengadakan aksi nyata dalam mengatasi masalah yang dimunculkan. Konsep-konsep yang telah dipahami siswa dapat diaplikasikan dalam kehidupan sehari-hari.

\section{Tahap Pemantapan Konsep}

Pelaksanakan pemantapan konsep ini dapat digunakan metode diskusi yang membahas tentang materi yang telah dipelajari dengan cara memberikan pertanyaan kepada siswa dan juga memberikan kesempatan kepada siswa untuk mengajukan pertanyaan. Pemantapan konsep ini dapat dilakukan ditengah-tengah proses pembelajaran, baik pada tahap pembentukan konsep maupun tahap aplikasi konsep. Pemberian kesempatan kepada siswa untuk mengajukan pertanyaan, guru dapat mengetahui apabila terjadi miskonsepsi.

\section{Tahap Penilaian}

Setelah guru melakukan pemantapan konsep dan merasa yakin bahwa siswa telah membantu dengan benar konsep yang telah dipahami, guru melakukan penilaian ini selesai, tahap ini juga mengakhiri rangkaian kegiatan pembelajaran dengan model pembelajaran STS.

Bauchspies (2006: 74) menyebutkan bahwa teknologi dan masyarakat sangat erat, rumit, dan terhubung secara timbal balik, 
teknologi sebagai perangkat atau sistem alat yang digunakan manusia untuk mengatur produksi, maka teknologi merupakan faktor penting dalam identifikasi diri orang sebagai masyarakat. Pengaitan pembelajaran sains dengan teknologi serta kegunaan dan kebutuhan masyarakat, konsep-konsep yang telah dipelajari dan dikuasai siswa diharapkan dapat bermanfaat bagi dirinya dan dapat digunakan untuk menyelesaikan masalah yang dihadapinya maupun masalah lingkungan sosialnya.

(Akcay \& Yager, 2010) mengemukakan hasil penelitiannya menunjukkan bahwa siswa yang diberikan pembelajaran dengan model STS yang berpusat pada siswa dicapai secara signifikan lebih baik daripada siswa yang diberikan pemeblajaran dengan model STS yang diarahkan oleh guru dalam hal pemahaman dan penggunaan keterampilan proses, penggunaan keterampilan kreativitas, pengembangan sikap yang lebih positif; dan kemampuan untuk menerapkan konsep sains dalam konteks baru.

Hal tersebut didukung oleh pendapat Bridgstock (1998:5) yang menjelaskan bahwa sains dan teknologi merubah semua aspek kehidupan manusia, baikitudi masa sekarang maupun di masa mendatang. Sains dan teknologi tersebut saling berkaitan dan tidak dapat dipisahkan dalam kehidupan manusia karena keduanyasaling berpengaruh. Chessin (1996: 34) mengatakan bahwa kurikulum STS sesuai dengan perspektif inkuiri di mana siswa adalah pembelajar aktif, berfokus pada kegiatan yang menggunakan pengetahuan ilmiah dan pemahaman teknologi untuk memecahkan masalah dan membuat keputusan menciptakan pengetahuan ilmiah.

Moore et al (2014: 69) mendeskripsikan bahwa prinsip dalam sains teknologi masyarakat menunjukkan pandangan pribadi dan sosial terkait dengan masyarakat dan masalah yang terjadi di lingkungan masyarakat. Selain hal tersebut sain teknologi juga menyajikan informasi tentang cara mengatasi isu-isu sosial yang ada di masyarakat. Pembelajaran dengan model STS ini akan memberikan pengalaman kepada siswa sehingga siswa lebih peka terhadap isuisu sosial yang ada di masyarakat. Kok (2014: 98) menjelaskan bahwa teori kognisi terletak mendefinisikan belajar sebagai pengetahuan dan keterampilan yang diperoleh dalam konteks yang mencerminkan cara-cara di mana pengetahuan dan keterampilan digunakan dalam kehidupan nyata. Pemahaman sejati berasal dari situasi di mana pembelajaran terjadi.

Poedjiadi(2005:121-123) mengungkapkan kelebihan dari model STS adalah sebagai berikut.

1. Siswa memiliki kreativitas yang lebih tinggi.

2. Kepedulian terhadap masyarakat dan lingkungan lebih besar.

3. Lebih mudah mengaplikasikan konsepkonsep yang dipelajari untuk kebutuhan masyarakat.

4. Memiliki kecenderungan untuk berpartisipasi dalam kegiatan menyelesaikan masalah di lingkungannya.

Science Technology and Society (STS) tidak hanya memberikan siswa tentang keterampilan kognitif saja tetapi juga dalam sosial. Siswa menjadi lebih peka terhadap permasalahan yang terjadi di lingkungan masyarakatnya. Mansour (2009: 290) berpendapat tren pendidikan saat ini adalah kemampuan yang membekali siswa untuk mengembangkan keterampilan observasi, klasifikasi, pengukuran, komunikasi, prediksi, deduksi, mengidentifikasi masalah, menetapkan hipotesis, merancang rencana penelitian, mengorganisir, dan menganalisis.

Martin (2009: 312) menjelaskan bahwa dalammodelSTSguru mengembangkanstudi tentang masalah dan masalah yang menarik bagi anak-anak. Anak-anak memiliki tingkat masukan yang tinggi dalam perencanaan pelajaran dan mengambil kepemilikan materi yang mereka kembangkan karena relevansinya dengan topik yang diteliti. Khine (2013: 29) berpendapat bahwa guru yang baik perlu mengetahui cara membuat pengaturan dan kegiatan bagi siswa untuk merestrukturisasi gagasan dan mencapai tingkat pemikiran dan pengetahuan yang 
lebih tinggi serta mempromosikannya baik secara verbal maupun praktis (melalui eksperimen dan metode penyelidikan). Wellington (2000: 3) menyampaikan bahwa belajar sains adalah, dalam banyak hal, seperti belajar bahasa baru. Dalam beberapa hal itu menghadirkan lebih banyak kesulitan karena banyak kata-kata sains yang sulit dan konseptual kadang-kadang definisi sains yang pasti, tetapi makna yang sangat berbeda dalam kehidupan sehari-hari.

Rauf (2013:48) berpendapat bahwa setiap siswa membutuhkan keterampilan proses baik itu ketika melakukan penyelidikan ilmiah maupun ketika proses pembelajaran. Kemudian Al Rabadi et al (2013: 137) menyebutkan bahwa proses ilmiah dapat membantu siswa dalam mengembangkan kemampuan dalam memecahkan masalah dan dapat membantu siswa dalam pengambilan keputusan secara mandiri. Keterampilan proses sains memungkinankan siswa untuk mengumpulkan informasi faktual yang mereka butuhkan untuk membangun, konsep, membentuk prinsipprinsip ilmiah, memahami teori. Ketika siswa terlibat dalam keterampilan proses, siswa mendeskripsikan objek dan peristiwa, mengajukan pertanyaan, membangun penjelasan, mencoba menjelaskan tentang pengetahuan ilmiah yang didapatkannya, dan berbagi ide mereka kepada orang lain. Selain itu siswa juga mengidentifikasi temuan dan pendapat mereka dengan berpikir kritis serta mempertimbangkan hasil temuannya. Ergul (2011:49) berpendapat bahwa keterampilan yang mendukung pembelajaran sains akan memastikan siswa dapat aktif dalam berpartisipasi, siswa dapat mengembangkan rasa tanggung jawab dalam mengikuti pembelajaran, meningkatkan pembelajaran, dan siswa dapat memperoleh cara penelitian dan metode yang dipakai, berpikir dan berperilaku seperti seorang ilmuwan. Hardianti \& Kuswanto (2017: 119) mengungkapkan bahwa peran guru adalah menyediakan pembelajaran yang melibatkan partisipasi siswa, seperti melakukan kegiatan pembelajaran yang kontekstual dan menggunakan sumber belajar yang dapat digunakan siswa secara langsung oleh siswa sehingga keterampilan proses sains siswa dapat terlatih. Di sisi lain guru juga dapat memberikan tugas atau pekerjaan rumah yang menggunakan keterampilan proses sains.

Gurses, et.al (2015: 645) mengungkapkan bahwa cara untuk memperoleh sebuah pengetahuan dilakukan dengan proses yang tidak instan, dan salah satu cara untuk memperoleh pengetahuan tersebut adalah dengan keterampilan proses sains. Keterampilan proses biasanya digunakan untuk melakukan penyelidikan. Keterampilan proses digunakan oleh para ilmuwan ketika meneleti masalah, isu, pertanyaan, maupun sebuah fenomena alam, namun sebenarnya keterampilan proses sains tidak hanya digunakan oleh para ilmuwan tetapi sudah digunakan seseorang sejak lahir. Yumusak (2016: 94) yang mengungkapkan bahwa "the science process skills that require more complex experiences such as the ability to observe that we delevop and utilize naturally even in our very early ages, in addition to comparison skills, data gathering, data interpretation, and ability to hypothesize". Keterampilan proses merupakan keterampilan yang mendasari keterampilan berpikir yang lebih kompleks. Keterampilan proses meliputi keterampilan dasar (basic science process skills) dan keterampilan terpadu (integrated science process skills).

Rustaman (2005: 2) mengelompokkan keterampilan proses sains secara lebih rinci menjadi enam yaitu sebagai berikut.

1. Mengamati

Di dalam mengamati terdapat kegiatan melihat, mencium, mendengar, mencicipi, meraba, dan mengukur yang melibatkan sebagaian atau seluruh alat indera. Hal-hal yang dapat diamati antara lain berupa gambar atau benda-benda yang diberikan kepada anak pada waktu kegiatan.

2. Menggolongkan atau mengklasifikasi

Menggolongkan atau mengklasifikasi merupakan suatu sistematika 
yang digunakan untuk mengatur objekobjek ke dalam sederetan kelompok tertentu. Kegiatanyang dapat dilakukan antara lain mencari persamaan suatu objek dalam kelompok dan menyusun obejk ke dalam suatu susunan berdasarkan kriteria tertentu, misalnya sifat dan fungsi.

3. Menggunakan alat dan melakukan pengukuran

Menggunakan alatdan pengukuran amat penting dalam sains. Penggunaan alat harus benar dan mengetahui alasan penggunaannya. Pengukuran juga harus dilakukan dengan cermat dan akurat.

4. Mengkomunikasikan

Kegiatan mengkomunikasikan ini melibatkan kemampuan mengutarakan dalam bentuk lisan, tulisan, gambar, grafik, dan persamaan. Kegiatan ini dapat melatih anak berbahasa yang benar agar dapat dimengerti oleh orang lain.

\section{Menginferensi}

Inferensi merupakan keterampilan dalam memberikan penjelasan atau interpretasi yang akan menuju pada suatu kesimpulan mengenai hasil observasi.

\section{Meramalkan atau memprediksi}

Keterampilan memprediksi merupakan suatu keterampilan membuat perkiraan tentang sesuatu yang belum terjadi berdasarkan sesuatu keuntungan atau pola yang sudah ada. Prediksi di dalam sains dibuat atas dasar observasi.

Ongowo \& Chisakwa (2013: 715) membagi keterampilan proses sains menjadi dua, yaitu keterampilan proses dasar yang terdiri dari menyimpulkan, mengamati, mengukur, berkomunikasi, mengklasifikasi, memprediksi, dan keterampilan proses sains terintegrasi yang terdiri dari mengendalikan variabel, mendefinisikan secara operasional, merumuskan variabel, menafsirkan data, bereksperimen dan merumuskan hipotesis dan berkomunikasi. Sependapat dengan Aka
\& Aydogdu (2010:19) membagi keterampilan proses sains menjadi dua, yaitu keterampilan proses dasar dan keterampilan proses sains terintegrasi.

Pengukuran keterampilan proses sains siswa dapat dilakukan dengan menggunakan instrument tertulis. Pelaksanaan pengukuran dapat dilakukan secara tes dan bukan tes. Penilaian melalui tes dapat dilakukan dalam bentuk tes tertulis. Sedangkan penilaian melalui bukan tes dapat dilakukan dalam bentuk observasi atau pengamatan.

1. Penilaian keterampilan proses melalui tes tertulis

Penilaian secara tertulis terhadap keterampilan proses sains dapat dilakukan dalam bentuk essai dan pilihan ganda. Pertanyaan yang disusun dalam bentuk pertanyaan konvergen dan pertanyaan divergen. Penilaian dalam bentuk essai memerlukan jawaban yang berupa pembahasan atau uraian kata-kata. Jawaban yang dituliskan siswa akan lebih bersifat subjektif, yang berarti menggambarkan pemahaman yang lebih individualistik.

Pengukuran keterampilan proses yang dilakukan melalui tes yang dikonstruksi dalam bentuk pertanyaan pilihan ganda, kemungkinan jawaban atas pertanyaan sudah disiapkan dan biasanya terdiri atas empat atau lima pilihan. Penilaian yang diperoleh dengan menggunakan pilihan jawaban dapat memberikan hasil yang lebih objektif, sebab jawaban atas masalah yang ada telah ditetapkan.

Arikunto (2009) menyatakan bahwa penilaian dalam bentuk pilihan ganda, lebih representative mewakili isi dan luas bahan atau materi. Di samping itu, dalam proses pemeriksaan dapat terhindar dari unsurunsur subjektivitas.

2. Penilaian keterampilan proses melalui bukan tes

Penilaian melalui keterampilan proses sains melalui bukan tes dapat dilakukan dalam bentuk observasi atau pengamatan. Pengamatan di sini dapat dilakukan secara langsung maupun tidak langsung. Selama proses kegiatan pembelajaran, guru dapat 
melakukan penilaian dengan mengamati perilaku siswa secara langsung dalam menunjukkan kemampuan keterampilan proses sains yang dimiliki.

Martin (2012: 24) mengemukakan bahwa keterampilan dasar (basic process skills) meliputi mengamati, mengklasifikasikan, mengkomunikasikan, mengukur, memprediksikan, dan menduga. Keterampilan terpadu (integrated process skills) meliputi keterampilan yang lebih kompleks seperti mengidentifikasi dan mengontrol variable, menginterpretasikan data, dan melakukan eksperimen. Sependapat dengan Settlage \& Southerland (2012:55) bahwa keterampilan proses dibagi menjadi dua kelompok, yaitu keterampilan dasar (basic skills) dan keterampilan lanjutan (integrated skills). Keterampilan dasar meliputi keterampilan untuk mengamati (observing), menduga (inferring), mengkalsifikasikan (classifying). Keterampilan lanjutan yaitu, mengukur (measuring), meramalkan (predicting), dan mengkomunikasikan (communicating).

Indikator keterampilan proses yang lebih spesifik dikemukakan oleh Samatowa (2016: 93).

1. Keterampilan melakukan observasi

Indikator seseorang dikatakan melakukan observasi antara lain:
a) menggunakan indera secara aman dan sesuai
b) mengenali perbedaan dan persama- an objek atau kejadian
c) mengenali urutan kejadian
d) mengamati suatu objek atau kejadi- an secara detail.

2. Keterampilan mengajukan hipotesis

Seseorang dikatakan mengajukan hipotesis jika:
a) menyarankan jawaban mengapa se- suatu terjadi
b) menggunakan pengetahuan awal untuk menjelaskan suatu kejadian
c) menyadari adanya kemungkinan lebih dari satu penjelasan dari suatu kejadian.

3. Keterampilan menginterpretasi data

Indikator seseorang melakukan interpretasi data antara lain:

d) memberikan interpretasi berdasarkan semua data yang tersedia

e) menguji suatu interpretasi dengan data yang baru

f) mendasarkan interpretasi pada pola atau hubungan data

g) menguji prediksi dari data dalam hal hubungan yang dapat diamati.

4. Keterampilan merencanakan percobaan Indikator merencanakan percobaan antara lain:

a) mengenali titik awal atau kejadian awal yang relevan dengan percobaan

b) mengenali variabel yang harus diubah dalam percobaan

c) mengenali variabel yang harus dibuat sama agar diperoleh suatu " $a$ fair test"

d) mengenali semua variabel yang harus dikendalikan

e) mengenali variabel yang sesuai untuk diukur atau dibandingkan.

5. Keterampilan melakukan investigasi, dengan indikator:

a) menentukan variabel bebas (yang diubah-ubah) dan variabel kontrol (yang harus dikendalikan atau dibuat tetap)

b) memanipulasi variabel agar percobaan benar-benar "fair"

c) mengidentifikasi variabel taut (variabel tergantung)

d) mengukur variabel taut dengan alat ukur yang sesuai

e) bekerja dengan tingkat ketelitian yang sesuai.

6. Keterampilan menarik kesimpulan, dengan indikator:
a) menggunakan berbagai informasi untuk membuat pernyataan dengan mengkombinasikan artinya
b) menemukan pola atau kecenderu- ngan hasil observasi/ percobaan


c) mengidentifikasi hubungan antara satu variable dengan variable lainnya

d) berhati-hati dalam menyampaikan asumsi tentang berlakunya kesimpulan.

7. Keterampilan mengkomunikasikan hasil, dengan indikator:

a) menyampaikan dan mengklarifikasikan ide/gagasan dengan lisan maupun tulisan

b) membuat catatan hasil observasi dalam percobaan

c) menyampaikan informasi dalam bentuk grafik, chart, atau tabel.

d) memilih alat komunikasi yang cocok agar mudah dipahami oleh orang lain.

Keterampilan proses sangat bermanfaat untuksiswa, khususnyasiswaSD. Care\&Ovens (1994:9) menyatakan bahwa keterampilan proses siswa umur 7 s.d. 11 tahun sangat perlu dikembangkan. Kegiatan pembelajaran tidak hanya untuk menguasai konsep saja tetapi juga untuk mengembangkan keterampilan. Sejalan dengan pendapat tersebut, Settlage \& Southerland (2012: 56) menjelaskan bahwa manfaat keterampilan proses antara lain yaitu sebagai alat sensemaking, mendukung perkembangan bahasa, membentuk komunitas pembelajar, dan dapat meningkatkan rasa ingin tahu.

\section{METODE}

Jenis penelitian ini adalah penelitian kuantitatif dengan menggunakan dengan menggunakan metode eksperimen semu (Quasi Eksperimen). Dikatakan eksperimen semu karena subjek (siswa) yang diberikan perlakukan tidak dapat terkontrol secara penuh. Adapun tahap-tahap yang akan dilaksanakan pada penelitian ini yaitu; 1) melakukan prasurvei dan mengajukan perizinan ke sekolah, 2) penyusunan instrument, validasi instrumen dan uji coba instrument, 3) melakukan survey penelitian, 4) melakukan koordinasi dengan guru kelas, 5) melakukan tes awal (pretest) dengan kelompok eksperimen maupun kelompok kontrol, 6) melakukan pembelajaran dengan model Science Technology and Society dan Quantum Teaching pada kelas eksperimen, sedangkan pada kelompok kontrol dengan model konvesional yaitu metode ceramah, 7) melakukan tes akhir (posttest) di kelompok eksperimen dan kelompok kontrol.

Tempat penlitian disini bertujuan untuk membatasi daerah dari variabel-variabel yang diteliti. Penelitian ini dilaksanakan di SD Gugus 1 Margoagung, Kecamatan Seyegan, Kabupaten Sleman. Pelaksanaan penelitian ini hanya mengambil sampel dua SD yaitu, SD Negeri Margoagung dan SD Ngino 1. Sampel penelitian yang digunakan diambil tiga kelas yaitu kelas IV SD Negeri Margoagung sebagai kelas eksperimen I, kelas IV SD Ngino 1 sebagai kelas kontrol. Rincinan jumlah masing-masing siswa yaitu, SD Negeri Margoagung sebanyak 25 siswa dan SD Negeri Ngino 1 sebanyak 24 siswa. Jumlah total seluruh siswa yaitu 54 siswa. Tema yang akan diambil dalam pelaksanaan penelitian ini adalah "Indahnya Keragaman di Negeriku" pada subtema satu. Kelas eksperimen akan diberikan perlakuan dengan model STS sedangkan kelas kontrol menggunakan model pembelajaran konvensional dengan metode ceramah.

Penelitian ini menggunakan uji validitas isi dan validitas empiris. Validitas isi berkenaan dengan kesanggupan instrumen mengukur isi yang harus diukur. Hal ini dapat diartikan bahwa alat ukur tersebut mempu mengungkap isi suatu konsep atau variabel yang hendak diukur. Pengujian validitas isi ini dilakukan dengan meminta pertimbangan ahli (expert judgement). Reliabilitas berhubungan dengan masalah kepercayaan. Suatu instrumen memiliki tingkat reliabilitas yang memadai, bila instrumen tersebut digunakan mengukur aspekyang diukurbeberapa kali hasilnya sama atau relatif sama. Semakin realibel suatu tes maka semakin yakin kita dapat menyatakan dalam hasil suatu tes mempunyai hasil yang sama ketika dilakukan tes kembali. Dalam penelitian ini uji realiabilitas menggunakan formula Alpha Cronbach.

Uji normalitas dilakukan terhadap data pretest dan posttest untuk kelompok 
histogram dari skor posttest keterampilan proses sains pada kelompok eksperimen yang menggunakan model STS ada pada gambar berikut.

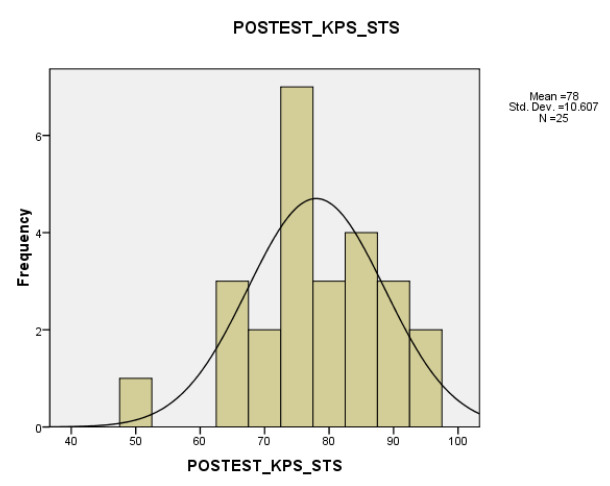

Gambar 2.

Histogram Posttest Keterampilan Proses Sains pada Kelompok Eksperimen Science Technology and Society

Berdasarkan histogram gambar 2. dapat diambil kesimpulan bahwa posttest keterampilan proses sains pada kelompok eksperimen yang menggunakan model STS terletak pada skor 75 dengan jumlah siswa sebanyak 7 siswa (28\%). Pengambilan kesimpulantersebut didasarkan pada perolehan skor 4 dan 3 dari setiap indikator. Perolehan skor yang sering muncul tersebut terdapat pada semua indikator keterampilan proses sains yaitu; (1) pengamatan: menggunakan indera yang sesuai, data lengkap, dan benar, (2) pengklasifikasian: menggolongkan data dengan jelas, lengkap, dan benar, 3) mengkomunikasikan: menyampaikan data dengan runtut dan sistematis, jelas, dan benar, (4) penyimpulan: kesimpulan yang disusun berlaku umum, jelas, dan benar, dan (5) mempredeksi: menggunakan pola-pola hasil pengamatan, gejala-gelaja yang akan terjadi, dan jelas.

Data keterampilan proses sains pada kelompok eksperimen dengan menggunakan model konvensional terdiri dari dua data, yaitu data pretest dan data posttest. Data tersebut disajikan dalam tabel berikut.

Tabel 3.

\section{Deskripsi Keterampilan Proses Sains dengan Model Konvensional}

\begin{tabular}{|l|c|c|}
\hline \multirow{2}{*}{\multicolumn{1}{|c|}{ Deskripsi }} & \multicolumn{2}{c|}{ Konvensional } \\
\cline { 2 - 3 } & Pre-test & Post-test \\
\hline Mean & 58,96 & 63,58 \\
\hline Median & 60 & 65 \\
\hline Modus & 45 & 65 \\
\hline Standar Deviasi & 12,60 & 12,24 \\
\hline Nilai Minimum & 40 & 40 \\
\hline Nilai Maksimum & 85 & 85 \\
\hline
\end{tabular}

Data deskripsi juga disajikan dalam bentuk histogram skor pretest keterampilan proses sains pada kelompok eksperimen yang menggunakan model konvensional.

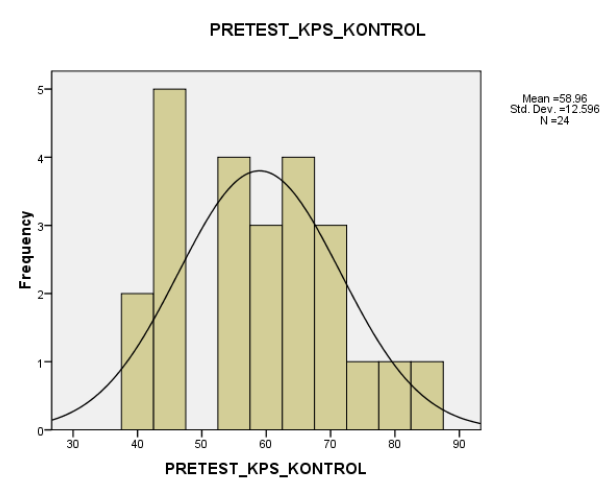

Gambar 3.

Histogram Pretest Keterampilan Proses Sains pada Kelompok Kontrol Konvensional

Berdasarkan histogram gambar 3. dapat diambil kesimpulan bahwa pretest keterampilan proses sains pada kelompok kontrol yang menggunakan model konvensional terletak pada skor 45 dengan jumlah siswa sebaganyak 5 siswa (20,83\%). Pengambilan kesimpulan tersebut didasarkan pada perolehan skor tertinggi dari setiap indikator yaitu 3. Perolehan skor yang sering muncul tersebut hanya terdapat pada satu indikator yaitu pengamatan: menggunakan indera yang sesuai, data lengkap, dan benar.

Data selanjutnya dilakukan dengan penentuan kecenderungan skor pretest keterampilan proses sains pada kelompok kontrol yang menggunakan model konvesional yang disajikan pada tabel berikut.

Tabel 4.

Kategori Kecenderungan Data Keterampilan Proses Sains pada Kelompok Kontrol Konvensional 
Agatha Asih Nugraheni dan Wuri Wuryandani, The Effect of Science Technology And Society Models ...

\begin{tabular}{|l|l|l|l|l|}
\hline No & Kategori & Interval & F & Persentase (\%) \\
\hline $\mathbf{1}$ & Baik & $80-100$ & 2 & $8,33 \%$ \\
\hline $\mathbf{2}$ & Cukup & $60-79$ & 11 & $45,83 \%$ \\
\hline 3 & Kurang & $<60$ & 11 & $45,83 \%$ \\
\hline & Jumlah & & 24 & $100 \%$ \\
\hline
\end{tabular}

Berdasarkan data diatas diketahui bahwa kategori kecenderungan pretest keterampilan proses sains pada kelompok kontrol yang menggunakan model konvensional yang berada pada kategori baik terdapat 2 siswa $(8,33 \%)$, kategori cukup terdapat 11 siswa $(45,83 \%)$, dan dikategori kurang terdapat 11 siswa $(45,83 \%)$. Kesimpulan yang diperoleh adalah bahwa kategori kecenderungan skor pretest keterampilan proses sains pada kelompok kontrol dengan menggunakan model konvensional berada pada kategori cukup dan kurang $(45,83 \%)$.

Selanjutnya deskripsi data dalam bentuk histogram dari skor posttest keterampilan proses sains pada kelompok kontrol yang menggunakan model konvensional ada pada gambar berikut.

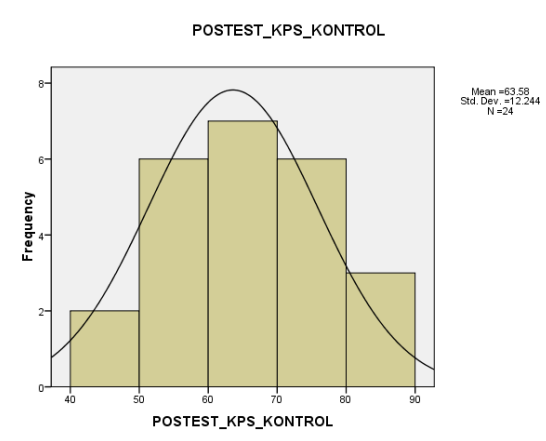

Gambar 4.

\section{Histogram Posttest Keterampilan Proses} Sains pada Kelompok Kontrol Konvensional

Berdasarkan histogram gambar 4. dapat diambil kesimpulan bahwa posttest keterampilan proses sains pada kelompok kontrol yang menggunakan model konvensional terletak pada skor 65 dengan jumlah siswa sebanyak 4 siswa (16,67\%). Pengambilan kesimpulan tersebut didasarkan pada perolehan skor tertinggi dari setiap indikator yaitu 3. Perolehan skor yang sering muncul tersebut terdapat pada dua indikator yaitu; (1) pengamatan: menggunakan indera yang sesuai, data lengkap, dan benar, dan (2) pengklasifikasian: menggolongkan data dengan jelas, lengkap.

Data selanjutnya dilakukan dengan penentuan kecenderungan skor posttest keterampilan proses sains pada kelompok kontrol yang menggunakan model konvensional yang disajikan pada tabel berikut.

\section{Tabel 5 .}

Kategori Kecenderungan Data Keterampilan Proses Sains pada Kelompok Kontrol Konvensional

\begin{tabular}{|l|l|l|l|l|}
\hline No & Kategori & Interval & F & $\begin{array}{l}\text { Persentase } \\
(\%)\end{array}$ \\
\hline 1 & Baik & $80-100$ & 3 & $28 \%$ \\
\hline 2 & Cukup & $60-79$ & 13 & $68 \%$ \\
\hline 3 & Kurang & $<60$ & 8 & $4 \%$ \\
\hline & Jumlah & & 24 & $100 \%$ \\
\hline
\end{tabular}

Berdasarkan data di atas diketahui bahwa kategori kecenderungan posttest keterampilan proses sains pada kelompok kontrol yang menggunakan model konvensional yang berada pada kategori baik terdapat 3 siswa $(12,50 \%)$, kategori cukup terdapat 13 siswa (54,17\%), dan kategori kurang terdapat 8 siswa (33,33\%). Kesimpulan yang diperoleh adalah bahwa kategori kecenderungan skor posttest keterampilan proses sains pada kelompok kontrol dengan menggunakan model konvensional berada pada kategori cukup (64\%).

Kriteriadalam pengujian yang digunakan dalam mengukur normalitas populasi penelitian ini adalah apabila Asymp. Sig > dari nilai alpha yang ditetapkan $\alpha=0,05$, sedangkan data tidak normal apabila Asymp. Sig $<$ dari tingkat alpha yang ditetapkan $\alpha=$ o,05. Uji normalitas di sini dilakukan menggunakan Kolmogorov-Simirmov dengan program SPSS 16.0 for windows. Hasil uji normalitas dengan menggunakan program SPSS 16.0 for windows dapat dilihat pada tabel berikut.

Perhitungan homogenitas di sini menggunakan uji F atau Levene yaitu untuk menguji data sebagai berikut. Data pretest keterampilan proses sains pada kelompok eksperimen yang menggunakan model Science Technology and Society, serta pada kelompok control yang menggunakan model pembelajaran konvensional dengan 
metode ceramah. Nilai signifikansi pada uji Levene pada kelompok eksperimen dengan model Science Technology and Society dan konvensional adalah lebih besar dari $\alpha=$ o,05. Kesimpulan yang dapat diambil yaitu varians kedua kelas adalah homogen.

$\mathrm{H}_{\mathrm{a}}$ : "Terdapat pengaruh yang signifikan model Science Technology and Society terhadap keterampilan proses siswa kelas IV SD se Gugus Margoagung Seyegan".

$\mathrm{H}_{\mathrm{o}}$ : "Tidak terdapat pengaruh yang signifikan model Science Technology and Society terhadap keterampilan proses sains siswa kelas IV SD se Gugus Margoagung Seyegan".

Pengambilan keputusan dan penarikan kesimpulan terhadap uji hipotesis dilakukan pada taraf signifikansi 0,05. Kriteria yang digunakan dalam pengambilan kesimpulan adalah jika peluang kesalahan < 0,05; maka hipotesis nihil $\left(\mathrm{H}_{\mathrm{o}}\right)$ ditolak, dan jika kesalahan > 0,05; maka hipotesis nihil $\left(\mathrm{H}_{\mathrm{o}}\right)$ diterima.

Berdasarkan hasil analisis data yang telah dilakukan menggunakan anova dengan independent sample t test, maka diperoleh hasil uji hipotesis sebagai berikut.

\section{Tabel 5.}

\section{Data Hasil Uji T-Test Keterampilan Proses} Sains dengan Model STS

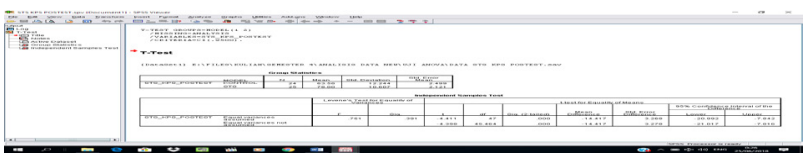

Hasil uji anova independent sample $t$ test pada variabel keterampilan proses sains diperoleh nilai F-hitung sebesar 0,751 dan $\mathrm{p}=$ o, $000<0,05$ maka $\mathrm{H}_{\mathrm{o}}$ dapat ditolak, sehingga dapat disimpulkan bahwa terdapat pengaruh yang signifikan model Science Technology and Society terhadap keterampilan proses sains. Berdasarkan hal tersebut maka hipotesis pertama yang menyatakan bahwa "Terdapat pengaruh yang signifikan model Science Technology and Society terhadap keterampilan proses sains siswa kelas IV SD se Gugus Margoagung Seyegan” diterima.

Hasil penelitian yang telah dilakukan diperoleh data yang menunjukkan adanya pengaruh model Science Technology and Society terhadap keterampilan proses sains siswa. Hal tersebut ditunjukkan dengan hasil perhitungan anova independent sample $t$ test yakni nilai $\mathrm{t}_{\text {hitung }}$ sebesar 0,751 dan nilai p sebesar o,ooo lebih kecil dari o,05 di mana $\mathrm{H}_{\mathrm{a}}$ diterima dan $\mathrm{H}_{\mathrm{o}}$ ditolak. Berdasarkan pernyataan tersebut maka dapat diartikan bahwa terdapat pengaruh model STS terhadap keterampilan proses sains siswa kelas IV SD di Gugus Margoagung Seyegan.

Moore et al (2014: 69) mendeskripsikan bahwa prinsip dalam sains teknologi masyarakat menunjukkan pandangan pribadi dan sosial terkait dengan masyarakat dan masalah yang terjadi di lingkungan masyarakat. Selain hal tersebut sain teknologi juga menyajikan informasi tentang cara mengatasi isu-isu sosial yang ada di masyarakat. Hal tersebut didukung oleh pendapat Aruna \& Smitha (2014: 54) bahwa sains dan teknologi sangat berpengaruh terhadap perkembangan masyarakat.

Penerapan model Science Technology and Society di kelas IV SD Negeri Margoagung Seyegan berlangsung dengan runtut. Hal tersebut dapat terlihat dari hasil observasi yang dilakukan oleh obsever dengan menggunakan lembar keterlaksanaan model pembelajaran. Guru menerapkan setiap langkah pembelajaran dan sintaks dari model STS tersebut. Sintaks dari pembelajaran STS tersebut menurut Poedjiadi (2005: 126) adalah; (1) pendahuluan: inisiasi/invitasi/ apersepsi/eksplorasi, (2) pembentukan/pengembangan konsep, (3) aplikasi konsep dalam kehidupan: penyelesaian masalah atau analisis isu, (4) pemantapan konsep, dan (5) penilaian. Poedjiadi (2005:126) juga menyebutkan beberapa kelebihan dari penerapan pembelajaran STS ini adalah sebagai berikut.

1. Siswa memiliki kreativitas yang lebih tinggi.

2. Kepedulian terhadap masyarakat dan lingkungan lebih besar.

3. Lebih mudah mengaplikasikan konsepkonsep yang dipelajari untuk kebutuhan 
Agatha Asih Nugraheni dan Wuri Wuryandani, The Effect of Science Technology And Society Models ...

masyarakat.

4. Memiliki kecenderungan untuk berpartisipasi dalam kegiatan menyelesaikan masalah di lingkungannya.

Berdasarkan hasil penelitian yang telah diperoleh dan diperkuat oleh beberapa teori di atas maka dapat disimpulkan bahwa pembelajaran dengan model Science Technology and Society berpengaruh signifikan dan lebih baik dibandingkan dnegan pembelajaran konvensional terhadap keterampilan proses sain siswa.

\section{SIMPULAN}

Penelitian ini menunjukkan adanya pengaruh yang signifikan model Science Technology and Society terhadap keterampilan proses sains siswa kelas IV SD se Gugus Margoagung Seyegan. Guru dapat menerapkan model Science Technology and Society dalam pembelajaran, hal tersebut dikarenakan penggunaan model STS memberikan dampak positif dalam meningkatkan keterampilan proses sains. Hal tersebut juga akan sangat bermanfaat untuk menambah referensi model dalam kegiatan pembelajaran supaya siswa tidak bosan dan mampu menerima materi yang disampaikan dengan baik.

\section{DAFTAR PUSTAKA}

Aka, E.I., Guven, E., \& Aydogdu, M. (2010). Effect of problem solving method on science process skills and academic achievement. Turkish Science Education Volume 7, Issues 4.

Akcay, H., \& Yager, R. E. (2010). The Impact of a Science / Technology / Society Teaching Approach on Student Learning in Five Domains, 602-611. https://doi. org/10.1007/s10956-010-9226-7

Al Rabadi, I. G, Al Momani, H.O., \& Al Rabadi, K. I. (2013). The effect of using process approach on science achievement and scientific attitudes among Jordanian basic stage students. Journal of Education and Pratice. 4, 136-
151.

Bridgstock, M., Burch, D., Furge, J., et al. (1998). Science technology society, an introduction. Mealbourne: Cambridge university press.

Bauchspies, W.K., Jennifer C., \& et.al. (2006). Science, Technology, and Society A Sociological Approach. USA: Black Publishing

Bybee, Rodger W. (2002). Learning Science and the Science of Learning. USA: Learning Science and the Science of Learning

Carre, C. \& Ovens, C. (1994). Science 7 - 11: developing primary teaching skills. New York: Routledge.

Conny, Semiawan, et.al. (1992). Pendekatan Keterampilan Proses. Jakarta: Rineka Cipta.

Dass. P.M., (2005). Using a science/ technology/society approach to prepare reform-oriented science teachers; the case of a secondary science methods course. Using a Science/Technology/ Society Approach, 14(1), 95-108.

del Rosario, B.I. (2009). Science, technology, society, and environment (stse) approach in environmental science for nonscience students in a local culture. Liceo Journal of Higher Education Research Science and Technology Section, 6(1), 269-183.

Ergul, R., Simsekli, Y., Calis, S., et al. (2011). The effect of Inquiry-Based Science Teaching on Elementary School Student's Science Process Skill and Science Attitudes. Bulgarian Journal of Science and Education Policy (BJSEP)

Feyzioglu, B., Demirdag, B., Akyildiz., M., et al. (2012). Developing a science process skill test for secondary students: validity and reliability study. Educational Science: Theory \& Pratice-12(3).

Gomleksiz, M.N. (2012). Elementary school students' perceptions of the new science and technology curriculum by gender. 
Educational Techology \& Society, 15 (1), 116-126).

Gurses, A., Centikaya, S., Dogar, C., Sahin, E. (2015). Determination of levels of use of basic process skills of high school students. Procedia - Social and Behavioral Sciences, 191, 644-650.

Hacieminoglu, E., Ali, M. M., \& Yager, R. E. (2015). Differences between Students in STS and Non-STS Classrooms Regarding Creativity, 3410.

Handika, I., \& Nur Wangid, M. (2013). Pengaruh Pembelajaran Berbasis Masalah Terhadap Penguasaan Konsep dan Keterampilan Proses Sains Siswa Kelas V. Jurnal Prima Edukasia, Volume I - Nomor 1, 2013.

Hardianti, T. \& Kuswanto, H. (2017). Difference among levels of inquiry: process skills improvement at Senior High School in Indonesia. International Journal of Instruction, 10 (2), $119-130$.

Harlen, W. (2000). Teaching, Learning and Assessing Science 5-12 $3^{\text {rd }}$ ed. London, England: Paul Chapman Publishing.

Hartono. (2007). Profil Keterampilan Proses Sains Mahasiswa Program Pendidikan Jarak Jauh S1 PGSD Universitas Sriwijaya. Seminar Proseeding of The International Seminar of Science Education, 27 Oktober 2007. Bandung.

Hidayati, et.al. (2008). Pengembangan Pendidikan IPS SD. Jakarta: Direktorat Jenderal Pendidikan Tinggi Departemen Pendidikan Nasional.

James, Trefil \& Robert. (2000). The Sciences an Integrated Approach: Second Edition. New York: John Wiley \& Sons, Inc.

Janbuala, S., Dhirapongse, S., Issaramanorose, N., \& Iembua, M. (2013). A study of using instructional media to enchance scientific process skill for young children in child development centers in Northeastern Area. International Forum of Teaching \& Studies, 9 (2), 41 -48 .
Khine, M. S., \& Issa M. S. (2013). Approaches and Strategies in Next Generation Science Learning. United States of America: Information Science Reference

Kok, Lyn \& Rika van Schoor. (2014). A ScienceTechnology-Society Approach To Teacher Education For The Foundation Phase: Students' empiricist views. South African Journal of Childhood Education 2014 4(1): 95-110 ISSN: 2223-7674

Mansour, N. (2009). Science-TechnologySociety (STS): A new paradign in Science Education. Bulletin of science, technology and society. 29(4), 287-297.

Martin, D. J. (2009). Elementary Science Methods A Constructivist Approach Fifth Edition. USA: Wadsworth Cengage Learning.

Moore, V.J., Mc-Cullogh, A.C., Chessin, D.A., et.al. (2014). Societal issues in social studies and science education: promoting responsible citizenship. International Journal of Humanities and Social Science, 4 (10), 69-73.

Nasution. S. (2011). Berbagai Pendekatan dalam Proses Belajar Mengajar. Jakarta: PT Bumi Aksara.

Ongowo, O. R., \& Indoshi, C.F. (2013). Science process skills in the Kenya certificate of secondary education biology practical examinations. Creative Education 2013. Vol.4, No.11, 713-717 Published Online November 2013 in Scires.

Ozgelen, S. (2012). Student' science process skills within a cognitive domain framework. Eurasia Journal of Mathematics, Science \& Technology Education, 8, 283-292.

Poedjiadi, Anna. (2010). Sains Teknologi Masyarakat. Bandung: PT Remaja

Rosdakarya.

Rauf, A.R.A., et.al. (2013). Inculcation of science process skills in a science classroom. Canadian Center of Science and Education, 9, 47-57. 
Riduwan. (2013). Skala Pengukuran Variabelvariabel Penelitian. Bandung:

Alfabeta.

Rustaman, Nuryani. (2005). Pengembangan Butir Soal Keterampilan Proses Sains. FPMIPA. UPI. http://onengdalilah. blogspot.com/2009/o2

Samatowa, U. (2016). Pembelajaran IPA di Sekolah Dasar. Jakarta: Indeks

Settledge, J. \& Southerland, S. (2012). Teaching science to every child: using culture as a starting point $2^{\text {nd }} e d$. New York: Routledge.

Shoimin, Aris. (2014). 68 Model Pembelajaran Inovatif dalam Kurikulum 2013. Yogyakarta: Ar-Ruzz Media.

Wellington, Jerry. (2000). Teaching and Learning Secondary Science. London: Routledge

Yumusak, G. K. (2016). Science Process Skills in Science Curricula Applied in Turkey. Journal of education and practice, 7 (20), $94-98$.

Ziman, John. (1980). Teaching and Learning about Science and Society. Australia: Press Syndicate of the University of Cambridge. 